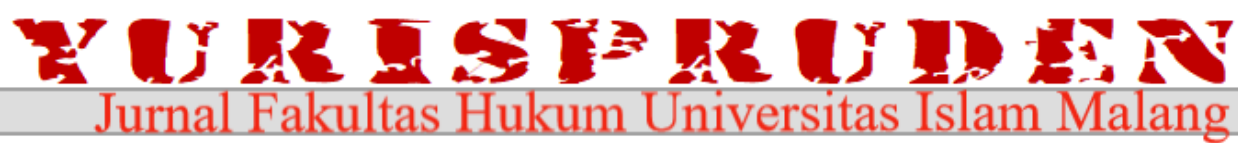 \\ Volume 5, Nomor 1, Januari 2022.
}

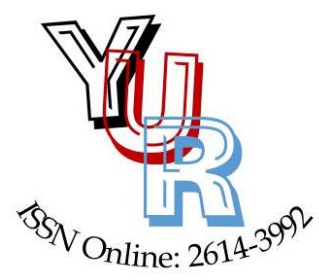

Editorial Office : Faculty of Law, Univeritas Islam Malang.

Jl. Mayjen Haryono No.193, Dinoyo, Kec. Lowokwaru, Malang, Provinsi Jawa Timur, 65144.

Phone $\quad$ : (0341) 551932 / 551822 / (0341) 552249

E-mail : : yurispruden@unisma.ac.id

Website $\quad:$ http://riset.unisma.ac.id/index.php/yur/index

\section{Karakteristik Perseroan Perorangan Sebagai Perseroan Yang Memenuhi Kriteria Untuk Usaha Mikro Dan Kecil}

\section{Amelia Sri Kusuma Dewi}

Fakultas Hukum Universitas Brawijaya

Jl. MT. Haryono No.169, Ketawanggede, Kec. Lowokwaru, Kota Malang, Jawa Timur 65145, (0341) 553898

Email: amelia_dewi@ub.ac.id

\section{Article}

Article History

Received: Dec 02, 2021;

Reviewed: Dec 23, 2021;

Accepted: Jan 15, 2022;

Published: Jan 20, 2022;

DOI:

10.33474/yur.v5i1.13747
Abstract

One of the obstacles for micro and small businesses to develop is the low quality of organizational operations. The Employment Creation Act selects the legal entity form of an individual company in order to empower micro and small businesses. Based on the Employment Act, companies that meet the criteria for micro and small businesses can be established by one person, whereas so far a legal entity has been established based on an agreement of at least two shareholders. The author chooses the formulation of the problem regarding the fulfillment of an individual company as a company that meets the criteria for micro and small businesses against the legal principles regarding a PT legal entity, so when viewed from the basic norms of establishment, organs, capital, and dissolution. By using a legal approach, it can be ascertained that companies that meet the criteria for micro and small businesses, judging from the basic norms of establishment, organs, capital, and dissolution, do not meet the legal principles regarding the legal entity $P T$.

Keywords: Legal Entities, Individual Companies, Micro and Small Enterprises.

Abstrak
Salah satu kendala bagi usaha mikro dan kecil untuk berkembang
adalah rendahnya kualitas operasional organisasi. Undang-undang
cipta kerja memilih bentuk badan hukum Perseroan Perorangan
dalam rangka memberdayakan usaha mikro dan kecil.
Berdasarkan undang-undang cipta kerja perseroan yang
memenuhi kriteria usaha mikro dan kecil dapat didirikan oleh satu
orang, padahal selama ini badan hukum didirikan, didirikan
berdasarkan perjanjian minimal dua pemegang saham. Penulis
memilih rumusan masalah mengenai pemenuhan perseroan
perorangan sebagai perseroan yang memenuhi kriteria untuk
usaha mikro dan kecil terhadap prinsip hukum tentang badan


hukum PT, demikian apabila dilihat dari norma dasar pendirian, organ, modal, serta pembubaran. Dengan menggunakan pendekatan undang-undang, dapat dipastikan bahwa perusahaan yang memenuhi kriteria untuk usaha mikro dan kecil, dilihat dari norma dasar pendirian, organ, modal, serta pembubaran, tidak memenuhi prinsip hukum tentang badan hukum PT.

Kata Kunci: Badan Hukum, Perseroan Perorangan, Usaha Mikro dan Kecil.

\section{PENDAHULUAN}

Pembukaan Undang-Undang Dasar Negara Republik Indonesia Tahun 1945 (UUD NRI 1945) mengamanahkan bahwa tujuan pembentukan Negara Republik Indonesia adalah mewujudkan masyarakat yang sejahtera, adil, makmur, yang merata, baik materiil maupun spiritual. Untuk menjalankan amanah konstitusi tersebut, maka dilaksanakan pembangunan nasional. Pembangunan nasional bertujuan untuk mewujudkan masyarakat adil dan makmur yang merata material dan spiritual berdasarkan Pancasila dan UUD NRI 1945 dalam wadah yang merdeka, bersatu, dan berkedaulatan rakyat dalam suasana perikehidupan bangsa yang aman, tertib, dan dinamis dalam lingkungan yang merdeka, bersahabat, dan damai.

Sejalan dengan amanat Pembukaan UUD NRI 1945 serta tujuan daripada pembangunan nasional, maka negara perlu melakukan berbagai upaya untuk memenuhi hak-hak warga negara untuk memperoleh pekerjaan dan penghidupan yang layak sebagaimana diatur pada Pasal 27 ayat (2) UUD NRI 1945. Selain itu kewajiban Pemerintah dalam pelaksanaan pembangunan nasional salah satunya diuraikan lebih lanjut pada Pasal 33 UUD RI 1945.

Pasal tersebut sejalan dengan amanat Ketetapan Majelis Permusyawaratan Rakyat Republik Indonesia Nomor XVI/MPRRI/1998 tentang Politik Ekonomi dalam rangka Demokrasi Ekonomi, Usaha Mikro, Kecil, dan Menengah (untuk selanjutnya disebut UMKM) perlu diberdayakan sebagai bagian integral ekonomi rakyat yang mempunyai kedudukan, peran, dan potensi strategis untuk mewujudkan struktur perekonomian nasional yang makin seimbang, berkembang, dan berkeadilan .

Perkembangan lingkungan perekonomian sudah berjalan cukup dinamis dengan pengaturan Undang-Undang Nomor 9 Tahun 1995 tentang Usaha Kecil. Namun tidak dipungkiri masih menghadapi berbagai hambatan dan kendala internal maupun eksternal, dalam hal produksi dan pengolahan, pemasaran, sumber daya manusia, desain dan teknologi, permodalan, serta iklim usaha. Selain itu peningkatkan kesempatan, kemampuan, dan perlindungan UMKM, juga belum optimal. Hal ini dikarenakan Undang- 
Undang Nomor 9 Tahun 1995 Tentang Usaha Kecil hanya mengatur Usaha Kecil.

Pemberdayaan UMKM selanjutnya menjadi agenda utama dari Undang-Undang Nomor 20 Tahun 2008 Tentang Usaha Mikro, Kecil, Dan Menengah (untuk selanjutnya disebut dengan UU UMKM). Tujuan daripada pemberdayaan UMKM adalah sebagaimana diatur oleh Pasal 5 UU UMKM, yaitu :

a. Mewujudkan struktur perekonomian nasional yang seimbang, berkembang, dan berkeadilan;

b. Menumbuhkan dan mengembangkan kemampuan Usaha Mikro, Kecil, dan Menengah menjadi usaha yang tangguh dan mandiri; dan

c. Meningkatkan peran usaha mikro, kecil, dan menengah dalam pembangunan daerah, penciptaan lapangan kerja, pemerataan pendapatan, pertumbuhan ekonomi, dan pengentasan rakyat dari kemiskinan.

Pada 2 November 2020, Undang-Undang Nomor 11 Tahun 2020 Tentang Cipta Kerja (untuk selanjutnya disebut UU Cipta Kerja) diundangkan, dimana terkait UMKM. Penjelasan umum undang-undang tersebut menyampaikan bahwa Indonesia masih menghadapi berbagai hambatan dalam berusaha, termasuk untuk Koperasi dan UMKM.

Pada konsideran menimbang juga menyampaikan bahwa untuk mendukung cipta kerja diperlukan penyesuaian berbagai aspek pengaturan, salah satunya yang berkaitan dengan kemudahan, perlindungan, dan pemberdayaan koperasi dan UMKM. Selain itu bahwa pengaturan yang berkaitan dengan hal tersebut, belum dapat memenuhi kebutuhan hukum untuk percepatan cipta kerja sehingga perlu dilakukan perubahan.

Salah satu kendala bagi UMKM untuk berkembang adalah rendahnya kualitas operasional organisasi. Maka mengubah bentuk badan UMKM sebagai badan usaha informal menjadi formal adalah salah satu upaya untuk memberikan kepastian hukum bagi UMKM dalam berkembang. Hal ini berkaca pada fakta bahwa jenis usaha besar yang memiliki produktivitas, laba, dan aset yang lebih baik ketimbang UMKM mayoritas telah berbentuk badan usaha formal.

Pada tanggal 25 November 2021, Mahkamah Konstitusi Republik Indonesia (untuk selanjutnya disebut dengan MK RI) telah membacakan Putusan Nomor 91/PUUXVIII/2020 terkait pengajuan uji materi dari beberapa pihak mengenai UU Cipta Kerja.

Putusan tersebut pada intinya menyebutkan bahwa UU Cipta Kerja bertentangan dengan UUD NRI 1945 dan tidak memiliki kekuatan hukum mengikat secara bersyarat sepanjang tidak dimaknai "tidak dilakukan perbaikan dalam waktu 2 (dua) tahun sejak putusan diucapkan." Namun, UU Cipta Kerja masih berlaku sampai dengan dilakukan pembentukan sesuai tenggang waktu yang ditetapkan dalam putusan.

Apabila tidak dilakukan perbaikan selama waktu yang telah ditetapkan maka UU Cipta Kerja menjadi inkonstitusional 
permanen. Kemudian dalam tenggang waktu sebagaimana yang telah ditetapkan, pembentuk undang-undang tidak dapat menyelesaikan perbaikan UU Cipta Kerja, maka UU Cipta Kerja dibatalkan dan undangundang, materi muatan, atau pasal-pasal yang telah dicabut maupun diubah dengan adanya UU Cipta Kerja akan berlaku kembali. Selain itu, Pemerintah juga dilarang menerbitkan peraturan pelaksana baru yang berkaitan dengan UU Cipta Kerja.

UU Cipta Kerja memilih bentuk badan hukum Perseroan Terbatas (untuk selanjutnya disebut dengan PT) sebagai bentuk badan usaha formal demikian dalam rangka memberdayakan UMKM, tetapi disini pilihan bentuk badan hukum PT tersebut hanya dibatasi untuk kriteria usaha mikro dan kecil saja (untuk selanjutnya disebut dengan UMK). Pasal 109 UU Cipta Kerja mengubah ketentuan Pasal 1 angka 1 Undang-Undang Nomor 40 Tahun 2007 tentang Perseroan Terbatas (untuk selanjutnya disebut dengan UU PT) menjadi sebagai berikut :

"Dalam undang-undang ini yang dimaksud dengan perseroan terbatas, yang selanjutnya disebut perseroan, adalah badan hukum yang merupakan persekutuan modal, didirikan berdasarkan perjanjian, melakukan kegiatan usaha dengan modal dasar yang seluruhnya terbagi dalam saham atau badan hukum perorangan yang memenuhi kriteria usaha mikro dan kecil sebagaimana diatur dalam peraturan perundang-undangan mengenai usaha mikro dan kecil."
UU Cipta Kerja juga mengubah ketentuan Pasal 7 ayat (7) UU PT, sehingga ketentuan yang mewajibkan perseroan didirikan oleh 2 (dua) orang atau lebih sebagaimana dimaksud pada ayat (1), ayat (5), serta ayat (6) UU PT tidak berlaku, salah satunya bagi perseroan yang memenuhi kriteria untuk UMK. Serta menegaskan lagi dengan menambahkan Pasal 153A, yang ayat (1) mengatur bahwa: "Perseroan yang memenuhi kriteria Usaha Mikro dan Kecil dapat didirikan oleh 1 (satu) orang."

Disinilah kemudian penulis merasa perlu untuk melakukan analisis terhadap isu hukum yang muncul mengenai keberadaan bentuk badan usaha baru yaitu PT yang kini dapat didirikan oleh 1 (satu) dan minimal 1 (satu) pemegang saham, yang selanjutnya dalam salah satu peraturan pelaksana UU Cipta Kerja yaitu Peraturan Pemerintah Nomor 8 Tahun 2021 Tentang Modal Dasar Perseroan Serta Pendaftaran Pendirian, Perubahan, Dan Pembubaran Perseroan (untuk selanjutnya disebut dengan PP MDP6) yang memenuhi kriteria untuk UMK dikenal dengan istilah perseroan perorangan.

Terkait badan hukum perseroan ini, demikian sebagai suatu bentuk perseroan yang memenuhi kriteria untuk UMK dan dimungkinkan sebagai suatu bentuk peluang pemberdayaan dan kemudahan berusaha bagi UMK, akan dianalisis oleh Penulis apakah telah memenuhi prinsip hukum tentang badan hukum Perseroan Terbatas? disini penulis 
akan membatasi obyek analisis pada norma substantif yang meliputi: pendirian, organ, modal, serta pembubaran dari perseroan perorangan.

Tujuan penulisan ini adalah mengetahui dan menganalisis pemenuhan karakteristik bentuk badan hukum perseroan perorangan sebagai perseroan yang memenuhi kriteria untuk UMK, terhadap prinsip hukum tentang badan hukum PT, demikian apabila dilihat dari norma substantif pendirian, organ, modal, serta pembubaran.

Hasil dari penelitian ini diharapkan dapat memberikan manfaat, secara teoritis, hasil penelitian ini menjadi kontribusi pemikiran terhadap pengembangan ilmu hukum, khususnya yang berkaitan dengan hukum perusahaan. Sedangkan secara praktis hasil penelitian ini dapat dijadikan pedoman bagi pelaku UMK, pihak ketiga dan/atau kreditor, maupun Kementerian Hukum dan Hak Asasi Manusia Republik Indonesia.

Berdasarkan dengan subtansi permasalahan hukum yang hendak dikaji dalam penelitian ini, maka penelitian ini dirancang sebagai suatu penelitian yang bersifat "normatif" (dogmatik). ${ }^{1} \quad$ Untuk mengkaji permasalahan yang ada, maka penelitian ini menggunakan pendekatan pendekatan perundang-undangan ${ }^{2}, \quad$ yakni pendekatan yang dilakukan dengan menelaah semua undang-undang dan regulasi yang bersangkutan dengan isu hukum. ${ }^{3}$

\section{PEMBAHASAN}

\section{Karakteristik Perseroan Perorangan}

Sebagai Perseroan Yang Memenuhi Kriteria Untuk Usaha Mikro Dan Kecil

Keberadaan perseroan perorangan merupakan sesuatu hal baru di Indonesia, meskipun di Indonesia telah lama dikenal model perusahaan yang dijalankan hanya dengan satu orang yang disebut perusahaan perseorangan, atau dikenal juga dengan istilah sole proprietorship atau sole trader. Bentuk usaha ini adalah bentuk usaha yang paling sederhana untuk dibuat.

\section{Zainal Asikin dan Wira Pria Suhartana} mendefinisikan perusahaan perseorangan sebagai perusahaan yang dilakukan oleh satu orang pengusaha. ${ }^{4}$ Perusahaan ini didirikan oleh satu orang, dimodali oleh satu orang, dan dijalankan oleh satu orang. ${ }^{5}$ Perusahaan ini pun tidak ada kewajiban untuk terdaftar, sehingga pembubarannya pun tidak memerlukan persetujuanpihaklain.

\footnotetext{
1 Terry Hutchinson, (2002), Researching and Writing in Law, Sydney: Lawbook. Hlm. (__ ), Lihat juga Ian Mcleod, (1993), Legal Method, London: Macmilan. hlm. (__).

2 Peter Mahmud Marzuki, (2005), Penelitian Hukum, Jakarta: Kencana. hlm. 93.

3 Johny Ibrahim, (2006), Teori dan Metode Penelitian Hukum Normatif, Malang: Bayumedia. hlm. 313-315, Lihat juga K. Zweigert H. Kotz, (1998), An Intoduction To Comparative Law, Oxford: Clarendon Press. hlm. 34-44.

${ }^{4}$ Zainal Asikin \& Wira Pria Suhartana, (2016), Pengantar Hukum Perusahaan, Edisi Pertama, Jakarta: Prenada Media Group. hlm. 6.

${ }^{5}$ Hendri Raharjo, (2009), Hukum Perusahaan, Cetakan Ke-1, Yogyakarta: Pustaka Yustisia. hlm. 26.
} 
Istilah yang dikenal di publik adalah Perusahaan Dagang (PD) atau Usaha Dagang (UD) pada dasarnya merupakan perusahaan perseorangan. Terhadap perusahaan perseorangan, tidak ditemukan pengaturan baik dalam Kitab UndangUndang Hukum Dagang (KUHD) maupun peraturan perundang-undangan lainnya. ${ }^{6}$

Perusahaan Perseorangan yang dikenal juga dengan PD atau UD meskipun samasama didirikan dan dimiliki oleh satu orang seperti halnya dengan perseroan perorangan, tetapi juga memiliki karakteristik yang berbeda dengan perseroan perorangan. Perusahaan Perseorangan yang dikenal juga dengan PD atau UD bukan merupakan badan hukum, sedangkan perseroan perorangan yang merupakan badan hukum.

Sebagai suatu negara yang mengadopsi sistem hukum Belanda, maka Belanda sendiri sejak tahun 1992 melalui Nieuw Burgerlijk Wetboek sebenarnya telah membuka peluang bahwa PT dapat didirikan oleh 1 (satu) orang saja. Hal ini dapat dilihat dalam terjemahannya pada buku 2 mengenai Legal Persons, Title 4 mengenai Companies Limited By Shares, Bagian 1 Pasal 64 ayat (2) yang mengatur bahwa: "A company shall be incorporated by one or more persons by notarial deed".
Di sejumlah negara, model PT perseorangan demikian sudah ada juga dengan istilah Single Member Private Limited Company di EU dan UK, Sendirian Berhad (Sdn Bhd) di Malaysia, dan Private Limited Company (Pte Ltd) di Singapura. Bahkan menariknya negara-negara diantaranya seperti Uganda, Ethiopia dan Pakistan sudah mengenal dan mempunyai regulasi PT perseorangan. $^{7}$

Pengertian PT selama ini mengacu pada Pasal 1 angka 1 UU PT, yang mengatakan bahwa:

"Perseroan terbatas, yang selanjutnya disebut perseroan, adalah badan hukum yang merupakan persekutuan modal, didirikan berdasarkan perjanjian, melakukan kegiatan usaha dengan modal dasar yang seluruhnya terbagi dalam saham dan memenuhi persyaratan yang ditetapkan dalam undang-undang ini serta peraturan pelaksanaannya."

Pasca keberlakuan UU Cipta Kerja, pengertian PT telah diubah menjadi sebagai berikut:

"Perseroan Terbatas, yang selanjutnya disebut Perseroan, adalah badan hukum yang merupakan persekutuan modal, didirikan berdasarkan perjanjian, melakukan kegiatan usaha dengan modal dasar yang seluruhnya terbagi dalam saham atau badan hukum perorangan yang memenuhi kriteria usaha mikro dan kecil sebagaimana diatur dalam peraturan perundang-undangan mengenai usaha mikro dan kecil."

\footnotetext{
${ }^{6}$ Zainal Asikin \& Wira Pria Suhartana, Op.Cit., hlm. 6-7.

${ }^{7}$ Muhammad Faiz Aziz dan Nunuk Febriananingsih, (April, 2020), Mewujudkan Perseroan Terbatas (PT) Perseorangan Bagi Usaha Mikro Kecil (UMK) Melalui Rancangan Undang-Undang Tentang Cipta Kerja, Jurnal RechtsVinding, Volume 9, Nomor 1. hlm. 91-108.
} 
Penyebutan badan hukum perorangan pada Pasal 109 angka 1 UU Cipta Kerja yang mengubah Pasal 1 angka 1 UU PT tersebut telah menambahkan ke dalam ruang lingkup PT yaitu:

"Badan Hukum perorangan yang memenuhi kriteria Usaha Mikro dan Kecil sebagaimana diatur dalam peraturan perundang-undangan mengenai Usaha Mikro dan Kecil."

Apa saja karakteristik Badan Hukum perorangan yang memenuhi kriteria UMK akan diuraikan oleh Penulis dibawah ini.

a. Perseroan perorangan merupakan badan hukum perorangan

Penulis bahas terlebih dahulu terkait redaksional pada Pasal 1 angka 1 tersebut di atas, adalah bahwa perseroan perorangan tersebut merupakan suatu badan hukum, dalam hal ini yaitu badan hukum perorangan. Secara normatif pengertian badan hukum (rechtspersoon, legel persons, persona moralis), yaitu batasan-batasan tentang badan hukum tidak dinyatakan dengan tegas dalam peraturan perundangan-undangan. Tetapi secara resmi dan tegas (eksplisit), penggunaan kata "Badan Hukum" telah tersebut dalam berbagai peraturan perundang-undangan.

Subyek hukum menurut Chidir Ali adalah manusia yang berkepribadian hukum dan segala sesuatu yang berdasarkan tuntutan kebutuhan masyarakat demikian itu oleh hukum diakui sebagai pendukung hak dan kewajiban. Mengenai siapakah subyek hukum itu, Chidir Ali menyatakan berdasarkan hukum positif bahwa dalam masyarakat pada dewasa ini subyek hukum adalah manusia (natuurlijk persoon) dan badan hukum (rechtspersoon). ${ }^{8}$

Chidir Ali menyimpulkan tentang pengertian badan hukum sebagai subyek hukum itu mencakup hal berikut, yaitu: perkumpulan orang (organisasi), dapat melakukan perbuatan hukum (rechtshandeling) dalam hubunganhubungan hukum (rechtshandeling), mempunyai harta kekayaan tersendiri, mempunyai pengurus, mempunyai hak dan kewajiban, dapat digugat atau menggugat di depan pengadilan. ${ }^{9}$

Penyebutan badan hukum perorangan pada Pasal 109 angka 1 UU Cipta Kerja yang mengubah Pasal 1 angka 1 UU PT merupakan sesuatu yang baru dalam pranata hukum perusahaan. Mengenai badan hukum perorangan dipertegas kembali pada Pasal 153A ayat (1) yang menyatakan bahwa perseroan yang memenuhi kriteria usaha mikro dan kecil dapat didirikan oleh 1 (satu) orang.

Kata "dapat" yang ada pada ayat tersebut berarti bahwa mengenai pendirian

\footnotetext{
${ }^{8}$ Chidir Ali, (1999), Badan Hukum, Bandung: Alumni. hlm. 11.

9 Ibid., hlm. 21.
} 
Perseroan yang memenuhi kriteria UMK adalah menjadi suatu alternatif atau pilihan, dimana Perseroan tersebut bisa didirikan oleh 1 (satu) orang atau boleh didirikan oleh 2 (dua) orang atau lebih. Salah satu peraturan pelaksana yang diundangkan dalam rangka untuk melaksanakan ketentuan Pasal 109 dan Pasal 185 huruf b UU Cipta Kerja yaitu PP MDP6.

Pasal 2 Ayat (1) Peraturan Pemerintah ini juga mengatur bahwa, Perseroan yang memenuhi kriteria untuk usaha mikro dan kecil terdiri atas: a. Perseroan yang didirikan oleh 2 (dua) orang atau lebih; dan b. Perseroan perorangan yang didirikan oleh 1 (satu) orang. Peraturan Pemerintah disini tampak menggunakan istilah yang berbeda yaitu perseroan perorangan, hal ini berbeda dengan istilah yang digunakan oleh UU Cipta Kerja yaitu badan hukum perorangan. Sehingga menurut penulis disini terjadi ketidak-konsistenan istilah antara UU Cipta Kerja dengan peraturan pelaksanaannya tersebut.

Penulis juga menyimpulkan dari Pasal 153A Ayat (1) UU PT dan Pasal 2 Ayat (1) PP MDP6 tersebut bahwa, hanya perseroan yang memenuhi kriteria untuk UMK saja yang dapat didirikan oleh 1 (satu) orang.

b. Memenuhi kriteria usaha mikro dan kecil sebagaimana diatur dalam peraturan perundang-undangan mengenai usaha mikro dan kecil
Pasal 1 angka 1, 2, dan 3 UU UMKM memberikan pengertian usaha mikro adalah

"Usaha produktif milik orang perorangan dan/atau badan usaha perorangan yang memenuhi kriteria Usaha Mikro sebagaimana diatur dalam Undang-Undang ini."

Yang dimaksud usaha kecil adalah usaha ekonomi produktif yang berdiri sendiri, yang dilakukan oleh orang perorangan atau badan usaha yang bukan merupakan anak perusahaan atau bukan cabang perusahaan yang dimiliki, dikuasai, atau menjadi bagian baik langsung maupun tidak langsung dari usaha menengah atau usaha besar yang memenuhi kriteria usaha kecil sebagaimana dimaksud dalam undang-undang ini. dan yang dimaksud dengan usaha menengah adalah:

"Usaha ekonomi produktif yang berdiri sendiri, yang dilakukan oleh orang perorangan atau badan usaha yang bukan merupakan anak perusahaan atau cabang perusahaan yang dimiliki, dikuasai, atau menjadi bagian baik langsung maupun tidak langsung dengan usaha kecil atau usaha besar dengan jumlah kekayaan bersih atau hasil penjualan tahunan sebagaimana diatur dalam undang-undang ini."

UMKM tidak dapat disamakan dengan bisnis biasa. Sebagai jenis usaha yang mempunyai karakteristik khusus, maka perlu dilihat prinsip-prinsip dasar UMKM dan apa tujuan yang ingin dicapai. Secara garis besar di Indonesia, prinsip tersebut dapat dilihat dalam asas-asas UMKM yang 
dapat ditemukan dalam Pasal 2 UU UMKM yang meliputi: kekeluargaan; demokrasi ekonomi; kebersamaan; efisiensi berkeadilan; berkelanjutan; berwawasan lingkungan; kemandirian; keseimbangan kemajuan; dan kesatuan ekonomi nasional.

Pascakeberlakuan UU Cipta Kerja, maka beberapa ketentuan khususnya Pasal 6 UU UMKM juga telah diubah, sehingga berbunyi sebagai berikut:

(1) Kriteria Usaha Mikro, Kecil, dan Menengah dapat memuat modal usaha, omzet, indikator kekayaan bersih, hasil penjualan tahunan, atau nilai investasi, insentif dan disinsentif, penerapan teknologi ramah lingkungan, kandungan lokal, atau jumlah tenaga kerja sesuai dengan kriteria setiap sektor usaha.

(2) Ketentuan lebih lanjut mengenai kriteria Usaha Mikro, Kecil, dan Menengah diatur dalam Peraturan Pemerintah.

Berdasarkan amanah Pasal 6 ayat (2) tersebut di atas, kemudian Pemerintah mengeluarkan Peraturan Pemerintah Nomor 7 Tahun 2021 Tentang Kemudahan, Pelindungan, dan Pemberdayaan Koperasi Dan UMKM. Menurut Peraturan Pemerintah tersebut bahwa UMKM dikelompokkan berdasarkan kriteria modal usaha atau hasil penjualan tahunan. ${ }^{10}$

Kriteria yang pertama adalah kriteria modal usaha yang digunakan untuk pendirian atau pendaftaran kegiatan usaha. Modal usaha tersebut merupakan modal sendiri dan modal pinjaman untuk menjalankan kegiatan usaha. Kriteria modal usaha terdiri atas:

a. Usaha Mikro memiliki modal usaha sampai dengan paling banyak Rp.1.000.000.000,00 (satu miliar rupiah) tidak termasuk tanah dan bangunan tempat usaha;

b. Usaha Kecil rnemiliki modal usaha lebih dari Rp.l.000.000.000,00 (satu miliar rupiah) sampai dengan paling banyak Rp.5.000.000. 000,00 (lima miliar rupiah) tidak termasuk tanah dan bangunan tempat usaha; dan

c. Usaha Menengah merniliki modal usaha lebih dari Rp.5.000.000.000,00 (lima miliar rupiah) sampai tlengan paling banyak Rp.10.000.000.000,00 (sepuluh miliar rupiah) tidak termasuk tanah dan bangunan tempat usaha.

Untuk pemberian kemudahan, pelindungan, dan pemberdayaan UMKM selain kriteria modal usaha, digunakan kriteria kedua, yaitu kriteria hasil penjualan tahunan. Kriteria hasil penjualan tahunan terdiri atas:

a. Usaha Mikro memiliki hasil penjualan tahunan sampai dengan Paling banyak Rp.2.000.000. 000,00 (dua miliar rupiah);

b. Usaha Kecil memiliki hasil penjualan tahunan lebih dari Rp.2.000.000.000,00 (dua miliar rupiah) sampai dengan Paling banyak Rp.15.000.000.000,00 (lima belas miliar rupiah); dan

c. Usaha Menengah memiliki hasil penjualan tahunan lebih dari Rp.15.000.000.000,00 (lima belas miliar rupiah) sampai dengan paling

10 Peraturan Pemerintah Nomor 7 Tahun 2021 Tentang Kemudahan, Pelindungan, dan Pemberdayaan Koperasi dan Usaha Mikro, Kecil, dan Menengah. 
banyak Rp.50.000.000.000,00 (lima puluh miliar rupiah).

Dalam hal pelaku usaha telah melaksanakan kegiatan usaha sebelum Peraturan Pemerintah ini mulai berlaku, pemberian kemudahan, pelindungan, dan pemberdayaan diberikan kepada UMKM yang memenuhi kriteria hasil penjualan tahunan. Nilai nominal kriteria dapat diubah sesuai dengan perkembangan perekonomian.

Untuk kepentingan tertentu, selain kriteria modal usaha dan hasil penjualan tahunan, kementerian/lembaga dapat menggunakan kriteria omzet, kekayaan bersih, nilai investasi, jumlah tenaga kerja, insentif dan disinsentif, kandungan lokal, dan/atau penerapan teknologi ramah lingkungan sesuai dengan kriteria setiap sektor usaha, yang dimaksud dengan kepentingan tertentu antara lain kepentingan pelaksanaan survei, sebagai alat ukur untuk membandingkan pemberdayaan UMKM di Indonesia dengan negara lain, serta untuk mengakomodir kepentingan sektor industri. Penggunaan kriteria selain kriteria modal usaha dan hasil penjualan tahunan tersebut oleh menteri teknis atau pimpinan lembaga harus mendapatkan pertimbangan dari Menteri.

Berdasarkan Pasal 109 angka 5 UU Cipta Kerja, bahwa diantara Pasal 153 dan Pasal 154 disisipkan 10 (sepuluh) pasal, yang salah satunya adalah Pasal $153 \mathrm{H}$ Ayat (1) yang mengatur bahwa:

"Dalam hal perseroan untuk usaha mikro dan kecil sudah tidak memenuhi kriteria usaha mikro dan kecil sebagaimana dimaksud dalam Pasal 153A, perseroan harus mengubah statusnya menjadi Perseroan sebagaimana dimaksud dalam ketentuan peraturan perundang-undangan yang berlaku."

Ketentuan lebih lanjut mengenai pengubahan status Perseroan untuk UMK menjadi Perseroan diatur dalam Pasal 9 PP MDP6.

(1) Perseroan perorangan harus mengubah status badan hukumnya menjadi Perseroan jika:

a. Pemegang saham menjadi lebih dari 1 (satu) orang: dan/atau

b. tidak memenuhi kriteria usaha mikro dan kecil sebagaimana diatur dalam ketentuan peraturan perundang-undangan mengenai usaha mikro dan kecil.

(2) Perseroan perorangan sebelum menjadi Perseroan sebagaimana dimaksud pada ayat (1) melakukan perubahan status melalui akta notaris dan didaftarkan secara elektronik kepada Menteri.

(3) Perubahan status sebagaimana dimaksud pada ayat dilaksanakan sesuai dengan ketentuan perundang-undangan mengenai Perseroan.

Perseroan perorangan sebagai perseroan yang memenuhi kriteria untuk UMK merupakan bentuk PT yang juga berstatus badan hukum, didirikan oleh 1 (satu) orang dan memenuhi kriteria untuk UMK.

Pemenuhan Karakteristik Perseroan Perorangan yang Memenuhi Kriteria 
Untuk Usaha Mikro Dan Kecil Sebagai Badan Hukum

Perseroan Perorangan sebagai perseroan yang memenuhi kriteria untuk UMK merupakan bentuk Perseroan Terbatas yang juga berstatus badan hukum. Untuk menentukan kriteria sebagai badan hukum, doktrin memberikan beberapa persyaratan, demikian agar suatu entitas badan usaha dapat memenuhi kriteria sebagai badan usaha yang berbadan hukum.

Menurut Maijers, suatu badan untuk dapat disebut sebagai badan hukum harus memenuhi syarat-syarat sebagai berikut, terdapat harta kekayaan terpisah lepas dari kekayaan anggotanya, ada kepentingan bersama yang diakui dan dilindungi oleh hukum, kepentingan tersebut haruslah stabil atau tidak terikat pada suatu waktu yang pendek saja, namun juga untuk waktu yang panjang; harus dapat ditunjukkan harta kekayaan tersebut tersendiri, yang tidak hanya untuk obyek tuntutan saja, tetapi juga untuk pemeliharaan kepentingan tertentu yang terlepas dari kepentingan anggotanya. ${ }^{11}$

Beberapa ahli menambahkan syarat formal agar suatu badan usaha dapat memenuhi karakteristik sebagai badan hukum, H.M.N. Purwosutjipto berpendapat bahwa agar dapat memiliki status sebagai badan hukum, suatu badan harus memenuhi unsur atau persyaratan yang bersifat material dan bersifat formal.

Persyaratan material meliputi, adanya harta kekayaan dengan tujuan yang terpisah dengan harta kekayaan pribadi para sekutu atau pendiri badan, kepentingan yang menjadi tujuan adalah kepentingan bersama; dan adanya beberapa orang sebagai pengurus badan tersebut, ${ }^{12}$ sedangkan persyaratan formal adalah adanya pengakuan dari negara yang mengakui suatu badan adalah badan hukum.

Pemenuhan karakeristik Perseroan Perorangan sebagai badan hukum, pertama kali akan dilihat dengan menganalisis apakah karakteristik "adanya harta kekayaan yang terpisah dari para pendirinya" telah terpenuhi. Keterpisahan antara harta kekayaan badan hukum dengan harta kekayaan pendirinya terjadi karena pada dasarnya masing-masing merupakan subyek hukum yang terpisah.

Dalam perspektif realist theory tentang badan hukum atau teori organ (organ theory) yang dikemukakan Otto Von Gierke, mempunyai pandangan bahwa badan hukum sama dengan manusia sebagai subjek hukum, badan hukum bersifat nyata, mempunyai kewenangan dan kedudukan, dan dapat bertindak melalui organ-organnya. Karena dia

11 Lisman Iskandar, (September-Desember, 1997), Aspek Hukum Yayasan Menurut Hukum Positif Di Indonesia, Majalah Yuridika, Nomor 5 \& 6, hlm. 24.

12 H.M.N. Purwosutjipto, (1982), Pengertian Pokok Hukum Dagang Indonesia, Jilid 2, Jakarta: Djambatan. hlm. 63. 
subjek hukum tersendiri, maka subjektivitasnya juga terpisah secara hukum (legally separate) dari para pendirinya dan atau anggotanya. ${ }^{13}$

Asas hukum corporate separate legal personality menyatakan dengan tegas bahwa PT merupakan suatu kesatuan hukum yang terpisah (separate legal entity) dari subjek hukum pribadi yang menjadi pendiri atau pemegang saham, sehingga tanggung jawab pemegang saham hanya terbatas sebesar nilai sahamnya (limited liability of it's shareholders).

Saham yang dimiliki oleh pemegang saham sebagai suatu bukti kepemilikan, pada umumnya hanya memberi hak kepada pemegang saham untuk mengeluarkan hak suara dalam RUPS, menerima dividen, menerima aset PT secara proporsional apabila terjadi likuidasi sesuai dengan jumlah saham yang dimiliki, mempunyai hak kontrol tidak langsung atas operasional sehari-hari PT dan atas segala kebijakan Direksi. ${ }^{14}$

Asas "limited liability" atau "pertanggungjawaban terbatas" tertuang pada Pasal 3 Ayat (1) UU PT:

"Pemegang saham Perseroan tidak bertanggung jawab secara pribadi atas perikatan yang dibuat atas nama Perseroan dan tidak bertanggung jawab atas kerugian Perseroan melebihi saham yang dimiliki."

Sedangkan pada Ayat (2) nya mengatur mengenai perkecualian keberlakuan asas tersebut diatas sebagai berlikut:

"Ketentuan sebagaimana dimaksud pada ayat (1) tidak berlaku apabila:

a. Persyaratan Perseroan sebagai badan hukum belum atau tidak terpenuhi;

b. Pemegang saham yang bersangkutan baik langsung maupun tidak langsung dengan itikad buruk memanfaatkan Perseroan untuk kepentingan pribadi;

c. Pemegang saham yang bersangkutan terlibat dalam perbuatan melawan hukum yang dilakukan oleh Perseroan; atau

d. Pemegang saham yang bersangkutan baik langsung maupun tidak langsung secara melawan hukum menggunakan kekayaan Perseroan, yang mengakibatkan kekayaan Perseroan menjadi tidak cukup untuk melunasi utang Perseroan."

Pertanggungjawaban terbatas pemegang saham perseroan untuk usaha mikro dan kecil dan perkecualiannya diatur secara khusus pada Pasal 153J Ayat (1) dan (2) UU Cipta Kerja. Demikian dengan redaksional yang sama dengan Pasal 3 UU PT. Berdasarkan pengaturan tersebut berarti perseroan perorangan telah memenuhi kriteria sebagai badan hukum yang utama yaitu adanya harta kekayaan yang terpisah dari pendirinya. Asas pertanggungjawaban terbatas (limited

13 Freddy Harris, (2007), Kedudukan Negara sebagai Penyerta Modal dalam PT. Persero, Pengubahan Ketentuan-Ketentuan Yang Tidak Sesuai dengan Prinsip-Prinsip Hukum Perusahaan, Disertasi Jakarta: Program Doktor Fakultas Hukum Universitas Indonesia, hlm. 21-22, dengan mengutip dari John D. Lewis, (1991), The Basic Consepts of State Law and The Most Recent State Law Theories, hlm. 158, Chidir Ali, (2005), Badan Hukum, Bandung: Alumni, hlm. 32-33, dan Van Aveldoren, (2001), Pengantar Ilmu Hukum, Jakarta: Pradnya Paramita. hlm. 196-197. Lihat juga dalam W. Friedman, (1953), Legal Teheory, London: Third Edition. Stevens \& Sons Limited. hlm. 59, 180-183.

14 M. Yahya Harahap, (2015), Hukum Perseroan Terbatas, Jakarta: Sinar Grafika. hlm. 73. 
liability) pemegang saham perseroan perorangan juga telah dimuat secara eksplisit dalam pasal 153 J Ayat (1) UU Cipta Kerja.

Pengakuan personalitas PT yang menyebabkan terjadinya pemisahan antara Perseroan dengan pemegang saham tidaklah bersifat mutlak, dalam hal tertentu pengadilan dapat meniadakan sifat kemandirian perseroan sehingga pemegang saham secara pribadi bertanggung jawab atas kewajiban perseroan. ${ }^{15}$

Konsekuensi hukum atas hapusnya tanggung jawab terbatas pemegang saham lazim disebut dengan piercing the corporate veil. ${ }^{16}$ Prinsip piercing the corporate veil merupakan prinsip yang membenarkan penghapusan tanggung jawab terbatas pemegang saham dalam keadaan-keadaan tertentu.

Penerobosan tanggung jawab terbatas pemegang saham melalui prinsip piercing the corporate veil dimaksudkan untuk mencegah terjadinya penyalahgunaan perlindungan hukum yang diberikan kepada pemegang saham berdasarkan prinsip limited liability. Doktrin piercing the corporate veil juga telah termuat dalam pasal $153 \mathrm{~J}$ ayat (2) UU Cipta Kerja. Sehingga sepanjang tidak adanya halhal sebagaimana disebutkan dalam Dalam pasal 153 J ayat (2) UU Cipta Kerja tersebut diatas, maka pemegang saham perseroan perorangan hanya bertanggungjawab sebatas modal/saham yang disertakannya.

Menurut penulis, meskipun karakteristik perseroan perorangan yang memenuhi kriteria untuk UMK telah memenuhi karakteristik sebagai Badan Hukum dengan adanya pengaturan pasal $153 \mathrm{~J}$ ayat (1) dan (2) UU Cipta Kerja tersebut di atas. Tetapi bahwa tetap ada risiko munculnya itikad buruk atau dilakukannya perbuatan melawan hukum bahkan kejahatan oleh satu-satunya pendiri atau pemegang saham pada perseroan perseorangan menjadi suatu kelemahan dan tantangan yang besar yang kemungkinan dapat terjadi pada perseroan perseorangan.

Mengingat bahwa

perseroan perseorangan didirikan dan dikendalikan oleh satu pemegang saham sehingga besar kemungkinan adanya fraud (kecurangan) yang dilakukan oleh pemegang saham yang bersangkutan terhadap pihak lain dengan memanfaatkan terbatasnya tanggung jawab yang dimiliki. Hal ini dikarenakan tidak adanya "check and balances" dalam pengambilan keputusan strategis perseroan perseorangan.

Meskipun terdapat konsep piercing the corporate veil atau lifting the veil yang bisa diberlakukan karena bagaimanapun Perseroan Perseorangan adalah bagian dari bentuk hukum PT, tetapi bagaimana

\footnotetext{
15 Hasbullah F. Sjawie, (2013), Direksi Perseroan Terbatas serta Pertanggungjawaban Pidana Korporasi, Bandung: Citra Aditya Bakti. hlm. 140 - 141.

16 M. Yahya Harahap, Op.Cit., hlm. 76.
} 
memastikan komitmen dari pemegang saham bahwa antara dirinya dan perseroan perorangan adalah subyek hukum yang terpisah dan bahwa pemegang saham tidak akan memanfaatkan terbatasnya tanggung jawab yang dimiliki.

Apalagi jika kemudian si pemegang saham juga sekaligus bertindak sebagai Direksi, mengingat tidak ada ketentuan dalam UU PT yang melarang pemegang saham merangkap jabatan sebagai Direksi maupun Dewan Komisaris. Hal ini perlu dipikirkan pengaturannya, demikian agar tidak hanya mengenai kemudahan berusaha untuk memberdayakan UMK di Indonesia saja yang tercapai tapi juga tetap memberikan perlindungan hukum kepada pihak ketiga.

Kekhawatiran ini semakin diperkuat dengan adanya rumusan Pasal 153E Ayat (2) UU Cipta Kerja, bahwa:

"Pendiri Perseroan hanya dapat mendirikan Perseroan Terbatas untuk Usaha Mikro dan Kecil sejumlah 1 (satu) Perseroan untuk usaha mikro dan kecil dalam 1 (satu) tahun."

Berdasarkan rumusan pasal a quo, maka dimungkinan bagi individu pelaku usaha UMK yang sama untuk mendirikan perseroan setiap tahunnya. Hal ini dikarenakan rumusan pasal a quo hanya mengatur batas minimum pendirian setiap tahunnya, bukan batas minimum pendirian per individu.
Hal ini tentunya menimbulkan permasalahan baru, yakni risiko terjadinya percabangan kreditur dan membuka kemungkinan bagi individu yang kemampuan aktualnya terbatas untuk terus mendirikan perseroan baru setiap tahunnya dengan dasar untuk mencari keuntungan dan mengandalkan sifat pertanggungjawaban terbatas (limited liability) perseroan.

\section{Pemenuhan Karakteristik Perseroan Perorangan Terhadap Prinsip Hukum} Badan Hukum Perseroan Terbatas:

\section{Terkait Norma Substantif Pendirian}

PT yang berbentuk persekutuan modal, harus didirikan berdasarkan perjanjian. Pengertian perjanjian telah diatur dalam Pasal 1313 Kitab Undang-Undang Hukum Perdata (KUHPdt), yang menyebutkan bahwa Perjanjian atau persetujuan adalah suatu perbuatan dengan mana satu orang atau lebih mengikatkan dirinya terhadap satu orang lain atau lebih. Kata persetujuan tersebut merupakan terjemahan dari perkataan overeekomst dalam Bahasa Belanda. Kata tersebut lazim diterjemahkan juga dengan kata perjanjian. Jadi persetujuan dalam Pasal 1313 Kitab KUHPdt tersebut sama artinya dengan perjanjian. ${ }^{17}$

Adapun pendapat para ahli mengenai perjanjian adalah sebagai berikut: R. Subekti, suatu perjanjian merupakan suatu peristiwa di mana seseorang berjanji kepada orang lain,

17 Sudikno Mertokusumo, (1985), Hukum Acara Perdata Indonesia, Yogyakarta: Liberty. hlm. 97. 
atau di mana dua orang saling berjanji untuk melaksanakan sesuatu hal. ${ }^{18}$ Wirjono Projodikoro, perjanjian adalah suatu hubungan hukum mengenai harta benda antara dua pihak dimana satu pihak berjanji untuk melakukan suatu hal atau tidak melakukan suatu hal janji sedangkan pihak lain menuntut pelaksanaannya. ${ }^{19}$

Sudikno Mertokusumo, perjanjian merupakan hubungan hukum antara dua pihak atau lebih berdasar kata sepakat untuk menimbulkan suatu akibat hukum. ${ }^{20}$ Hubungan hukum tersebut terjadi antara subyek hukum yang satu dengan subyek hukum yang lain, dimana subyek hukum yang satu berhak atas prestasi dan begitu juga suyek hukum yang lain berkewajiban untuk melaksanakan prestasinya sesuai dengan yang telah disepakati. ${ }^{21}$

Abdul Kadir Muhammad, bahwa yang disebut perjanjian adalah suatu persetujuan dengan dimana dua orang atau lebih saling mengikatkan diri untuk melaksanakan suatu hal dalam lapangan harta kekayaan. ${ }^{22}$

Ketentuan yang menerapkan prinsip bahwa PT adalah didirikan berdasarkan perjanjian tersebut sejalan dengan ketentuan Pasal 7 ayat (1), dimana perseroan didirikan oleh 2 (dua) orang atau lebih dengan akta notaris yang dibuat dalam bahasa Indonesia.

Pengertian akta notaris menurut Pasal 1 angka 7 Undang-Undang Nomor 30 Tahun 2004 tentang Jabatan Notaris sebagaimana telah diubah melalui Pasal I angka 1 UndangUndang Nomor 2 Tahun 2014 Tentang Perubahan Atas Undang-Undang Nomor 30 Tahun 2004 tentang Jabatan Notaris, bahwa yang dimaksud dengan akta notaris yang selanjutnya disebut akta adalah akta autentik yang dibuat oleh atau di hadapan notaris menurut bentuk dan tata cara yang ditetapkan dalam undang-undang ini.

Akta Notaris sebagai alat bukti otentik, maka pengertian akta otentik itu sendiri dapat dilihat pada ketentuan Pasal 1868 KUHPdt bahwa suatu akta otentik adalah suatu akta yang dibuat dalam bentuk yang ditentukan oleh undang-undang oleh atau di hadapan pejabat umum yang berwenang untuk itu di tempat akta itu dibuat.

Akta-akta yang dibuat, walaupun ditandatangani oleh para pihak, namun tidak memenuhi persyaratan Pasal 1868 KUHPdt, tidak dapat diperlakukan sebagai akta otentik, hanya mempunyai kekuatan sebagai tulisan di bawah tangan, demikian pengeturan berdasarkan Pasal 1869 KUHPdt. Akta

18 R. Subekti, (2001), Pokok-Pokok Hukum Perdata, Jakarta: Intermasa. hlm. 36, lihat juga R. Subekti, (2006), Aneka Perjanjian, Bandung: Citra Aditya Bakti, hlm. 1.

19 Wirjono Prodjodikoro, (1981), Asas-Asas Hukum Perjanjian, Bandung: Sumur. hlm. 9.

20 Sudikno Mertokusumo, Op.Cit, hlm. 97-98.

21 Sudikno Mertokusumo, (2008), Ilmu Hukum, Yogyakarta: Liberty. hlm. 21.

22 Abdul Kadir Muhammad, (1992), Hukum Perikatan, Bandung: Citra Aditya Bakti. hlm. 78. 
Notaris memiliki nilai kepastian hukum dan merupakan alat bukti yang sempurna di Pengadilan.

Akta otentik mempunyai kekuatan pembuktian yang sempurna dan mengikat siapapun yang terikat dengan akta tersebut, sepanjang tidak bisa dibuktikan sebaliknya berdasarkan putusan pengadilan. ${ }^{23}$ Hal mana juga telah diatur secara tegas pada Pasal 1870 KUHPdt, bahwa dalam hukum pembuktian perdata, akta notaris merupakan akta otentik yang mempunyai kekuatan pembuktian yang sempurna.

Seiring dengan semangat yang diusung dalam UU Cipta Kerja, yaitu untuk memberikan kemudahan berusaha khususnya bagi UMK, persyaratan tersebut diubah dimana pendirian PT dengan kriteria UMK dapat didirikan oleh 1 (satu) orang. Mekanisme pendirian Perseroan Perorangan tersebut telah diatur pada Pasal 109 angka 5 UU Cipta Kerja dengan menyisipkan Pasal 153A, 153B dan 153C diantara Pasal 153 dengan Pasal 154 sebagai berikut:

Pasal 153A:

(1) Perseroan yang memenuhi kriteria usaha mikro dan kecil dapat didirikan oleh 1 (satu) orang.

(2) Pendirian perseroan untuk usaha mikro dan kecil sebagaimana dimaksud pada ayat (1) dilakukan berdasarkan surat pernyataan pendirian yang dibuat dalam Bahasa Indonesia.

(3) Ketentuan lebih lanjut mengenai pendirian perseroan untuk usaha mikro dan kecil diatur dalam peraturan pemerintah."

Pasal 153B:

(1) Pernyataan pendirian sebagaimana dimaksud dalam Pasal 153A ayat (2) memuat maksud dan tujuan, kegiatan usaha, modal dasar, dan keterangan lain berkaitan dengan pendirian perseroan.

(2) Pernyataan pendirian sebagaimana dimaksud pada ayat (1) didaftarkan secara elektronik kepada Menteri dengan mengisi format isian.

(3) Ketentuan lebih lanjut mengenai materi pernyataan pendirian sebagaimana dimaksud pada ayat (1) dan format isian sebagaimana dimaksud pada ayat (2) diatur dalam peraturan pemerintah.

Ketentuan lebih lanjut mengenai pendirian Perseroan untuk UMK serta pernyataan pendirian dan format isian telah diatur pada Pasal 6 dan 7 PP MDP6.

Pasal 6:

(1) Perseroan perorangan didirikan oleh Warga Negara Indonesia dengan mengisi pernyataan pendirian dalam bahasa Indonesia.

(2) Warga Negara Indonesia sebagaimana dimaksud pada ayat (1) harus memenuhi persyaratan:

a. berusia paling rendah 17 (tujuh belas) tahun; dan

b. cakap hukum.

(3) Perseroan perorangan memperoleh status badan hukum setelah didaftarkan kepada Menteri dan mendapatkan sertifikat pendaftaran secara elektronik.

(4) Perseroan perorangan yang telah memperoleh status badan hukum sebagaimana dimaksud pada ayat (3) diumumkan oleh Menteri dalam laman resmi direktorat jenderal yang menyelenggarakan tugas dan fungsi di bidang administrasi hukum umum.

23 Habib Adjie, (2015), Kebatalan dan Pembatalan Akta Notaris, Bandung: Refika Aditama. hlm. 6. 
Dalam hal pemenuhan karakteristik perseroan perorangan terhadap prinsip hukum badan hukum PT terkait norma pendirian, terdapat beberapa hal yang menurut Penulis dianggap tidak memenuhi prinsip hukum badan hukum PT. Yang Pertama, bahwa Pendirian Perseroan Perorangan untuk UMK yang hanya dengan surat pernyataan menarik untuk dicermati. PT adalah badan hukum yang memiliki konsekuensi sebagai subyek hukum pendukung hak dan kewajiban serta pemisahan harta kekayaan pendiri dengan PT.

Oleh karena itu, pada Pasal 7 Ayat (1) UU PT mensyaratkan akta pendirian yang dibuat oleh Notaris. Akta Notaris merupakan suatu akta yang memiliki peran penting dalam kelangsungan sebuah PT. Bahkan pada UU PT, terdapat perbuatan-perbuatan hukum yang diwajibkan dibuat dalam bentuk Akta Notaris, selain pendirian PT, antara lain perubahan anggaran dasar, ${ }^{24}$ pengambilalihan saham yang dilakukan langsung dari pemegang saham, ${ }^{25}$ penggabungan, peleburan, pengambillihan, atau pemisahan, ${ }^{26}$ serta pembubaran $\mathrm{PT}^{27}$

Menurut penulis, pendirian perseroan perorangan untuk UMK yang hanya didirikan berdasarkan surat pernyataan tanpa akta notaris tidak sesuai dengan prinsip-prinsip hukum PT. Pendirian PT yang hanya melalui surat pernyataan tidak menjamin legalitas dokumen dan identitas pendiri. Legalitas PT akan diragukan dan beresiko. Konsekuensi PT maupun Perseroan Perorangan sebagai badan hukum, maka legalitas dokumen dan identitas pendiri harus dapat dipertanggungjawabkan. Oleh karena itu, pernyataan pendirian yang dibuat oleh dan/atau dihadapan Notaris tetap perlu untuk menjamin legalitas Perseroan Perseorangan, keabsahan dokumen dan identitas pendiri walaupun hanya untuk UMK.

Kedua, mengenai persyaratan mendirikan Perseroan Perorangan sebagaimana diatur pada Pasal 6 PP MDP6, salah satunya adalah pendiri tersebut harus memenuhi syarat berusia paling rendah 17 tahun dan cakap hukum. Syarat tersebut tentu saja menjadi bertentangan dengan dengan beberapa ketentuan peraturan perundangan-undangan yang paling sering dijadikan dasar untuk menentukan batas usia yang dianggap cakap melakukan perbuatan hukum tertentu yaitu pada Pasal 330 KUHPdt (21 tahun atau telah kawin), Pasal 47 Ayat (1) Undang-Undang Nomor 1 Tahun 1974 (18 tahun atau telah kawin) serta Pasal 39 Ayat (1) UndangUndang Nomor 30 Tahun 2004 Tentang Jabatan Notaris Sebagaimana Diubah Dengan Undang-Undang Nomor 2 Tahun 2014 Tentang Perubahan Atas Undang-Undang

24 Pasal 21 Undang-Undang Nomor 40 Tahun 2007 tentang Perseroan Terbatas.

25 Pasal 128 ayat (2) Undang-Undang Nomor 40 Tahun 2007 tentang Perseroan Terbatas.

26 Pasal 128 ayat (1) Undang-Undang Nomor 40 Tahun 2007 tentang Perseroan Terbatas.

27 Pasal 142 ayat (1) jo. Pasal 90 ayat (2) Undang-Undang Nomor 40 Tahun 2007 tentang Perseroan Terbatas. 
Nomor 30 Tahun 2004 Tentang Jabatan Notaris (18 tahun atau telah kawin). Dikarenakan Perseroan Perorangan adalah badan hukum maka seharusnya dalam pendiriannya, si pendiri tentu saja wajib memenuhi ketentuan kecakapan dalam melakukan perbuatan hukum.

Hal ketiga yang dianalisis oleh penulis yaitu mengenai kapan saat PT termasuk perseroan perorangan mendapatkan status sebagai badan hukum. Pasal 7 ayat (4) UU PT mengatur bahwa Perseroan memperoleh status badan hukum pada tanggal diterbitkannya Keputusan Menteri mengenai pengesahan badan hukum Perseroan.

Tetapi pascakeberlakuan UU Cipta Kerja yang mengubah ketentuan Pasal 7 ayat (4) UU PT, dimana perseroan tidak lagi memperoleh status badan hukum pada tanggal diterbitkannya Keputusan Menteri mengenai pengesahan badan hukum perseroan, melainkan saat ini perseroan memperoleh status badan hukum setelah didaftarkan kepada Menteri dan mendapatkan bukti pendaftaran.

Selanjutnya Pasal 6 ayat (3) PP MDP6 mengatur bahwa perseroan perorangan memperoleh status badan hukum setelah didaftarkan kepada Menteri dan mendapatkan sertifikat pendaftaran secara elektronik.

Beberapa ahli menyampaikan syarat formal agar suatu badan usaha dapat memenuhi karakteristik sebagai badan hukum. Diantaranya adalah H.M.N. Purwosutjipto yang berpendapat bahwa agar dapat memiliki status sebagai badan hukum, suatu badan harus memenuhi unsur atau persyaratan yang bersifat material dan bersifat formal. Persyaratan formal nya adalah adanya pengakuan dari negara yang mengakui suatu badan adalah badan hukum. ${ }^{28}$ Pengakuan negara yang mengakui bahwa PT adalah suatu badan hukum dilakukan melalui pengesahan menteri dalam keputusannya mengenai pengesahan status badan hukum Perseroan.

Menurut Jimly Asshiddiqie, dalam praktek dikenal adanya tiga macam norma hukum yang dapat diuji atau biasa disebut sebagai norm control mechanism. Ketiganya sama-sama merupakan bentuk norma hukum sebagai hasil dari proses pengambilan keputusan hukum yaitu: (i) keputusan normatif yang berisi dan bersifat pengaturan (regeling); (ii) keputusan normatif yang berisi dan bersifat penetapan administratif (beschikking); dan (iii) keputusan normatif yang berisi dan bersifat penghakiman (judgement) yang biasa disebut vonis (Belanda : vonnis). ${ }^{29}$

Ketiga bentuk norma hukum tersebut di atas, ada yang merupakan individual and concrete norms, dan ada pula yang merupakan general and abstract norms. Vonnis dan beschikking selalu bersifat individual and

28 H.M.N. Purwosutjipto, Op.Cit., hlm. 63.

29 Jimly Asshiddiqie, (2006), Hukum Acara Pengujian Undang-Undang, Jakarta: Konstitusi Press. hlm.1. 
concrete, sedangkan regeling selalu bersifat general and abstract. ${ }^{30}$

Selain itu, menurut Maria Farida Indrati Soeprapto, suatu keputusan (beschikkiking) bersifat sekali-selesai (enmahlig), sedangkan peraturan (regeling) selalu berlaku terusmenerus (dauerhaftig). ${ }^{31}$

Berdasarkan hal-hal tersebut di atas, Penulis menyimpulkan bahwa keberadaan Keputusan Menteri mengenai pengesahan status badan hukum Perseroan ini menurut penulis tidak bisa digantikan begitu saja dengan bukti pendaftaran maupun sertifikat pendaftaran secara elektronik. Hal ini dikarenakan Keputusan Menteri merupakan salah satu bentuk norma hukum, yaitu keputusan normatif yang berisi dan bersifat penetapan administratif (beschikking), sedangkan bukti pendaftaran maupun sertifikat pendaftaran secara elektronik bukan merupakan norma hukum.

\section{Pemenuhan Karakteristik Perseroan Perorangan Terhadap Prinsip Hukum} Badan Hukum Perseroan Terbatas:

\section{Terkait Norma Organ}

Salah satu karakteristik yang dimiliki badan hukum, diantaranya adalah ada pengurus/organisasi yang teratur. UU Cipta Kerja tidak mengubah pengaturan pada UU PT terkait dengan keberadaan organ Perseroan Pengorangan. Dengan demikian dalam hal organ perusahaan, Perseroan Perorangan tetap mempunyai susunan organ yang sama dengan PT yaitu Rapat Umum Pemegang Saham (RUPS), Direksi, dan Dewan Komisaris.

Dalam hal pemenuhan karakteristik perseroan perorangan terhadap prinsip hukum badan hukum PT terkait norma Organ, menurut penulis terdapat 1 (satu) hal yang tidak memenuhi prinsip hukum badan hukum PT. Hal ini dikarenakan menurut penulis, tidak tepat apabila menggunakan istilah RUPS untuk menyebut salah satu organ pada perseroan perorangan. Hal ini dikarenakan pada perseroan perorangan pemegang saham hanya terdiri dari 1 orang saja.

Ketidaktepatan tersebut muncul pada redaksional Pasal 153C ayat (1) UU Cipta Kerja, yang mengatur hal sebagai berikut:

"Perubahan pernyataan pendirian perseroan untuk usaha mikro dan kecil sebagaimana dimaksud dalam Pasal 153A ditetapkan oleh RUPS dan diberitahukan secara elektronik kepada Menteri."

Sedangkan terkait keputusan yang diambil dalam pelaksanaan RUPS, yang biasa disebut dengan Keputusan RUPS, maka pada Perseroan Perorangan digunakan istilah Keputusan Pemegang Saham. Hal mana mengenai penggunaan istilah Keputusan Pemegang Saham untung saja

30 Ibid., hlm. 2.

31 Maria Farida Indrati Soeprapto, (2007), Ilmu Perundang-Undangan (1) (Jenis, Fungsi, Materi, Muatan), Yogyakarta: Kanisius. hlm. 78. 
telah diakomodir pada PP MDP6 di beberapa pasalnya, yaitu:

a. Pasal 8 ayat (5): Perubahan sebagaimana dimaksud pada ayat (2) dan ayat (3) ditetapkan dengan keputusan pemegang saham perseroan perorangan yang mempunyai kekuatan hukum sama dengan rapat umum pemegang saham.

b. Pasal 13 ayat (1): Pembubaran Perseroan perorangan ditetapkan dengan keputusan pemegang saham perseroan perorangan yang mempunyai kekuatan hukum sama dengan rapat umum pemegang saham yang dituangkan dalam pernyataan pembubaran dan diberitahukan secara elektronik kepada Menteri.

c. Pasal 13 ayat (2) huruf a: Pembubaran Perseroan perorangan sebagaimana dimaksud pada ayat (1) terjadi karena: a. berdasarkan keputusan pemegang saham Perseroan perorangan yang mempunyai kekuatan hukum sama dengan rapat umum pemegang saham.

Tetapi menurut penulis selain terjadi ketidaktepatan istilah pada produk hukum undang-undangnya juga telah terjadi ketidaksinkronan istilah antara produk hukum undang-undang dengan peraturan pemerintah sebagai peraturan pelaksananya, jika terjadi konflik norma seperti ini, maka dapat diselesaikan dengan asas lex superior derogat legi inferiori yang bermakna peraturan perundang-undangan (norma/aturan hukum) yang lebih tinggi meniadakan keberlakuan peraturan perundang-undangan (norma/ aturan hukum) yang lebih rendah. Dalam sistem hukum Indonesia, jenis dan hierarki peraturan perundang-undangan diatur dalam ketentuan Pasal 7 dan Pasal 8 UndangUndang Nomor 12 Tahun 2011 tentang Pembentukan Peraturan PerundangUndangan, dimana undang-undang disini lebih tinggi hierarkinya/ kedudukannya dibandingkan peraturan pemerintah.

Semakin jelas bahwa karakteristik perseroan perorangan terkait norma substantif organ menurut penulis tidak memenuhi prinsip hukum badan hukum PT selama UU Cipta Kerja masih menggunakan istilah RUPS untuk organ perseroan perseorangan, dikarenakan pada perseroan perorangan hanya ada orang pemegang saham sehingga tidak mungkin ada organ perseroan perorangan yang bernama RUPS dan tidak mungkin dilaksanakan RUPS.

\section{Pemenuhan Karakteristik Perseroan} Perorangan Terhadap Prinsip Hukum Badan Hukum Perseroan Terbatas:

\section{Terkait Norma Substantif Modal}

UU PT mengatur bahwa ada 3 (tiga) jenis modal pada PT, yaitu modal dasar, modal yang ditempatkan dan modal yang disetor. Modal dasar (maatschappelijk kapitaal atau authorized capital atau nominal capital) yaitu jumlah modal yang disebutkan dalam 
Anggaran Dasar (AD) PT. ${ }^{32}$ Modal yang ditempatkan (subscribed capital/issued capital) adalah modal yang telah disanggupi oleh para pendiri ataupun pemegang saham untuk dibayarkan atau disetorkan ke dalam kas Perseroan. ${ }^{33}$ Modal yang disetor (gestort kapitaal atau paid up capital) adalah modal perseroan yang berupa sejumlah uang tunai atau bentuk lainnya yang diserahkan pada pendiri kepada kas perseroan pada saat perseroan didirikan. ${ }^{34}$ Hal ini merupakan proporsi nominal saham yang benar-benar dibayar pemegang saham. ${ }^{35}$

Pasal 32 ayat (1) UU PT mengatur bahwa: "Modal dasar Perseroan paling sedikit Rp 50.000.000,00 (lima puluh juta rupiah)." Sedangkan mengenai besaran modal ditempatkan dan disetornya diatur pada Pasal 33 ayat (1), dimana "Paling sedikit 25\% (dua puluh lima persen) dari modal dasar sebagaimana dimaksud dalam Pasal 32 harus ditempatkan dan disetor penuh."

UU PT dalam pelaksanaan ketentuan minimal modal dasar ternyata menyulitkan dunia usaha, khususnya bagi pengusaha pemula. Oleh karena itu, pemerintah merasa perlu melakukan penyesuaian peraturan yang dimaksudkan untuk memberikan kemudahan berusaha, dan lebih menjamin ketertiban dunia usaha. Ketentuan kemudahan berusaha tersebut telah diatur pada Peraturan Pemerintah Nomor 29 Tahun 2016 Tentang Perubahan Modal Dasar PT yang telah mencabut peraturan sebelumnya yaitu Peraturan Pemerintah Nomor 7 Tahun 2016 Tentang Perubahan Modal Dasar Perseroan Terbatas. Peraturan pemerintah tersebut mengubah ketentuan terhadap modal dasar PT menjadi diserahkan sepenuhnya pada kesepakatan para pendiri PT.

Pasca diundangkannya UU Cipta Kerja, melalui Pasal 109 angka 3 UU Cipta Kerja menegaskan lagi mengenai tidak diperlukannya pengaturan mengenai batas minimal modal dasar sebagai berikut :

(1) Perseroan wajib memiliki modal dasar Perseroan

(2) Besaran modal dasar Perseroan sebagaimana dimaksud pada ayat (1) ditentukan berdasarkan keputusan pendiri Perseroan.

(3) Ketentuan lebih lanjut mengenai modal dasar Perseroan diatur dalam Peraturan Pemerintah.

Pengaturan mana ditegaskan kembali pada Pasal 3 PP MDP6. Menurut penulis, secara filosofis, perlindungan modal dan kekayaan perseroan sebagaimana dimaksud dalam Pasal 32 ayat (1) dan (2) Undang Nomor 40 Tahun 2007 tentang Perseroan Terbatas sebelum diubah adalah untuk

32 Farida Hasyim, (2009), Hukum Dagang, Cetakan Pertama, Jakarta: Sinar Grafika. hlm. 152.

33 Agus Sardjono, Yetty Komalasari Dewi, Rosewitha Irawaty, Togi Pangaribuan, (2014), Pengantar Hukum Dagang, Cetakan Kedua, Jakarta: RajaGrafindo Persada. hlm. 83.

34 David Kelly, et.al, (2014), Business Law, dikutip dari Ridwan Khairandy, Pokok-Pokok Hukum Dagang Indonesia, Yogyakarta: FH UII Press. hlm. 81-82.

35 Ibid., hlm. 75. 
mempersatukan dan menjaga keutuhan kekayaan perseroan agar pembayaran dividen maupun interim dividen yang dilakukan perseroan kepada para pemegang saham atau mereka yang berhak atas keuntungan tidak akan mengganggu dana cadangan modal perseroan. Selain itu juga bertujuan agar pihak ketiga mendapatkan perlindungan hukum ketika melakukan kerjasama atau bermitra dengan sebuah PT.

Dalam kondisi sebagaimana yang diatur dalam UU Cipta Kerja, dimana kemungkinan pendirian perseroan oleh satu subyek hukum perorangan dan tidak ada ketentuan mengenai minimum modal dasar, maka perlindungan modal dan kekayaan perseroan serta resiko gagal pembayaran oleh perseroan sangat mungkin terjadi. Hal ini dikarenakan tidak adanya jaminan modal yang bisa dijadikan sebagai sarana kepentingan pelunasan piutang kreditur. Disinilah menurut penulis, karakteristik perseroan perorangan terhadap prinsip hukum badan hukum PT terkait norma substantif modal dianggap tidak memenuhi.

Mengenai besaran modal ditempatkan dan disetor diatur pada Pasal 4 ayat (1) PP MDP6.

"Modal dasar Perseroan sebagaimana dimaksud dalam Pasal 3 harus ditempatkan dan disetor penuh paling sedikit 25\% (dua puluh lima persen) yang dibuktikan dengan bukti penyetoran yang sah."

Pada akhirnya, Pasal 5 PP MDP6 mengatur bahwa:
"Perseroan yang melaksanakan kegiatan usaha tertentu, besaran minimum modal dasar Perseroan harus sesuai dengan ketentuan peraturan perundangundangan."

Pasal ini lah yang kemudian menurut penulis menjadi penyelamat terkait pemenuhan karakteristik perseroan perorangan terhadap prinsip hukum badan hukum PT terkait norma substantif modal, yang jika hanya merujuk pada UU Cipta Kerja dianggap tidak memenuhi. Pasal ini mengamanahkan agar dalam menentukan besaran minimum modal dasar perseroan harus sesuai dengan ketentuan peraturan perundang-undangan terkait.

Peraturan Pemerintah Nomor 7 Tahun 2021 tentang Kemudahan, Pelindungan, dan Pemberdayaan Koperasi Dan UMKM telah mengatur mengenai kriteria UMK. Salah satunya berdasarkan kriteria modal usaha. Hanya saja pada pasal tersebut maupun penjelasannya tidak dijelaskan apakah modal usaha tersebut merupakan modal dasar, modal ditempatkan ataukah modal disetor, sehingga sulit menerapkan apa yang diatur pada Pasal 4 ayat (1) PP MDP6 tersebut di atas.

\section{Pemenuhan Karakteristik Perseroan}

Perorangan Terhadap Prinsip Hukum Badan Hukum Perseroan Terbatas:

\section{Terkait Norma Substantif Pembubaran}

Mengenai pembubaran perseroan perorangan diatur pada Pasal $135 \mathrm{G}$ ayat (1) UU Cipta Kerja bahwa: 
"Pembubaran perseroan untuk usaha mikro dan kecil sebagaimana dimaksud dalam Pasal 153A dilakukan oleh RUPS yang dituangkan dalam pernyataan pembubaran dan diberitahukan secara elektronik kepada Menteri."

Penggunaan istilah RUPS kurang tepat menurut Penulis dikarenakan pada Perseroan Perorangan hanya ada 1 (satu) orang pemegang saham. Penyebutan yang tepat tercantum pada Pasal 13 ayat (1) PP MDP6 sebagai berikut:

"Pembubaran perseroan perorangan ditetapkan dengan keputusan pemegang saham perseroan perorangan yang mempunyai kekuatan hukum sama dengan rapat umum pemegang saham yang dituangkan dalam pernyataan pembubaran dan diberitahukan secara elektronik kepada Menteri."

Sesuai dengan analisis Penulis pada bahasan sebelumnya selain terjadi ketidaktepatan istilah pada produk hukum undangundang, juga telah terjadi ketidaksinkronan istilah antara produk hukum undang-undang dengan peraturan pemerintah sebagai peraturan pelaksanannya.

Karakteristik perseroan perorangan terkait norma substantif pembubaran menurut penulis tidak memenuhi prinsip hukum badan hukum PT selama pada UU Cipta Kerja tetap menggunakan istilah RUPS, dikarenakan pada perseroan perorangan hanya ada 1 (satu) orang pemegang saham sehingga tidak mungkin dilaksanakan RUPS dalam rangka pembubaran.

\section{KESIMPULAN}

Perseroan perorangan telah memenuhi kriteria sebagai badan hukum yaitu adanya harta kekayaan yang terpisah dari pendirinya. Tetapi, karakteristik bentuk badan hukum perseroan perorangan sebagai perseroan yang memenuhi kriteria untuk usaha mikro dan kecil, demikian apabila dilihat dari norma substantif pendirian, organ, modal, serta pembubaran, belum memenuhi prinsip hukum tentang badan hukum PT. Sehingga dalam pendirian dan operasionalnya, celah hukum yang ada dapat memberikan akibat hukum baik perseroan perorangan itu sendiri maupun bagi pihak lain yang berhubungan dengan perseroan perorangan tersebut.

\section{SARAN}

Pemerintah bersiap terkait kemungkinan adanya celah hukum dalam pengaturan perseroan perorangan sebagai suatu bentuk badan hukum yang memenuhi kriteria untuk usaha mikro dan kecil, demikian dengan mengeluarkan peraturan pelaksana terkait beberapa hal yang menjadi catatan kritis berbagai pihak terkait norma substantif pengaturan perseroan perorangan agar dapat memenuhi prinsip hukum badan hukum PT.

Perlu dilakukan sosialisasi terkait norma substantif pengaturan perseroan perorangan oleh instansi dan kementerian terkait.

Pemerintah melalui instansi terkait perlu menata sistem UMK yang komprehensif yang meliputi perbaikan kualitas SDM yang menjalankan kegiatan UMK, mekanisme 
pendirian badan usahanya, permodalannya dan pengawasannya.

\section{DAFTAR PUSTAKA}

\section{Jurnal}

Muhammad Faiz Aziz dan Nunuk Febriananingsih, (April, 2020), Mewujudkan Perseroan Terbatas (PT) Perseorangan Bagi Usaha Mikro Kecil (UMK) Melalui Rancangan UndangUndang Tentang Cipta Kerja, Jurnal RechtsVinding, Volume 9, Nomor 1.

\section{Skripsi/ Thesis/ Disertasi}

Freddy Harris, (2007), Kedudukan Negara sebagai Penyerta Modal dalam PT. Persero, Pengubahan KetentuanKetentuan Yang Tidak Sesuai dengan Prinsip-Prinsip Hukum Perusahaan, Disertasi Jakarta: Program Doktor Fakultas Hukum Universitas Indonesia.

\section{Majalah}

Lisman Iskandar, (September-Desember, 1997), Aspek Hukum Yayasan Menurut Hukum Positif Di Indonesia, Majalah Yuridika, Nomor 5 \& 6.

\section{Buku}

Abdul Kadir Muhammad, (1992), Hukum Perikatan, Bandung: Citra Aditya Bakti.

Agus Sardjono, Yetty Komalasari Dewi, Rosewitha Irawaty, Togi Pangaribuan, (2014), Pengantar Hukum Dagang, Cetakan Kedua, Jakarta: RajaGrafindo Persada.

Chidir Ali, (1999), Badan Hukum, Bandung: Alumni.

David Kelly, et.al, (2014), Business Law, dikutip dari Ridwan Khairandy, PokokPokok Hukum Dagang Indonesia, Yogyakarta: FH UII Press.

Farida Hasyim, (2009), Hukum Dagang, Cetakan Pertama, Jakarta: Sinar Grafika.
H.M.N. Purwosutjipto, (1982), Pengertian Pokok Hukum Dagang Indonesia, Jilid 2, Jakarta: Djambatan.

Habib Adjie, (2015), Kebatalan dan Pembatalan Akta Notaris, Bandung: Refika Aditama.

Hasbullah F. Sjawie, (2013), Direksi Perseroan Terbatas serta Pertanggungjawaban Pidana Korporasi, Bandung: Citra Aditya Bakti.

Hendri Raharjo, (2009), Hukum Perusahaan, Cetakan Ke-1, Yogyakarta: Pustaka Yustisia.

Jimly Asshiddiqie, (2006), Hukum Acara Pengujian Undang-Undang, Jakarta: Konstitusi Press.

Johny Ibrahim, (2006), Teori dan Metode Penelitian Hukum Normatif, Malang: Bayumedia.

M. Yahya Harahap, (2011), Hukum Perseroan Terbatas, Jakarta: Sinar Grafika.

Maria Farida Indrati Soeprapto, (2007), Ilmu Perundang-Undangan (1) (Jenis, Fungsi, Materi, Muatan), Yogyakarta: Kanisius.

Peter Mahmud Marzuki, (2005), Penelitian Hukum, Jakarta: Kencana.

R. Subekti, (2001), Pokok-Pokok Hukum Perdata, Jakarta: Intermasa.

Sudikno Mertokusumo, (1985), Hukum Acara Perdata Indonesia, Yogyakarta: Liberty.

Sudikno Mertokusumo, (2008), Ilmu Hukum, Yogyakarta: Liberty.

Terry Hutchinson, (2002), Researching and Writing in Law, Sydney: Lawbook.

Wirjono Prodjodikoro, (1981), Asas-Asas Hukum Perjanjian, Bandung: Sumur.

Zainal Asikin \& Wira Pria Suhartana, (2016), Pengantar Hukum Perusahaan, Edisi Pertama, Jakarta: Prenada Media Group. 